\title{
Forced labor of Jews in the Szydlowiec ghetto during World War II - The nature of the work performed, its dimension and social aspects

\author{
Marlena Bodo
}

Ph.D. Student, Uniwersytet Jagielloński, Poland.

Email: marlena.bodo@gmail.com

\author{
Keywords \\ Jews, Forced Labor, Social Aspects, World War \\ II, Work Performance.
}

\section{Article History}

Received on $8^{\text {th }}$ September 2021

Accepted on $9^{\text {th }}$ October 2021

Published on $18^{\text {th }}$ October 2021

\section{Cite this article}

Bodo, M. (2021). Forced labor of Jews in the Szydłowiec ghetto during World War II - The nature of the work performed, its dimension and social aspects. Humanities \& Social Sciences

Reviews, 9(5), 57-6`1.

https://doi.org/10.18510/hssr.2021.959

Copyright @Author

Publishing License

This work is licensed under a Creative Commons Attribution-Share Alike 4.0 International License

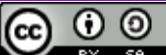

\begin{abstract}
Purpose of the study: The article contains information on the forced labor performed by Jews for the benefit of Germans during the Second World War. The research area was narrowed down to the area of the Szydłowiec ghetto and its vicinity (the Radom district in the General Government. The text presents the types of work performed by Jews, forms of forcing them to take up forced labor, and their attempts to bypass German restrictions.
\end{abstract}

Methodology: This article is based on a comparative-historical method, the aim of which is to enable the researcher to identify Jews as a separate social group that was used by the Germans for forced labor. The use of this method is aimed at learning about the historical processes and mechanisms of functioning of selected Nazi restrictions in Poland. In addition, prosopographic and inductive methods as well as a method based on the grounded theory will be used. Moreover, due to the nature of the subject of the work, the research conducted in this field also requires the use of oral history.

Main Findings: Extremely burdensome, in many aspects, compulsion for Jews was the almost slave labor they performed for the benefit of the Germans. Every Jew had to work at least one day a week for the Third Reich. Jews were used for various types of work, including snow removal from roads. Slave labor for the benefit of the Nazis was one of the causes of the increasing poverty of Jews.

Application: The results of the research make a significant contribution to the knowledge of the history of Jews from Szydłowiec. This research not only broadens the knowledge about the history of the functioning of the Jewish community in Szydłowiec during World War II, but also broadens the knowledge about the history of the Holocaust and the mechanisms of crimes. These studies can be used to further analyze the situation of Jews during the German occupation in the territory of the Radom district, or more broadly, in the territory of the General Government.

Novelty/Originality of the study: For the first time in this study, many fragments of Jewish diaries from the Memorial Book of Szydłowiec were used (some of the memoirs were published only in Yiddish). The article is the basis for further research on the history of Jews during World War II in the area of the Radom district.

\section{INTRODUCTION}

Not only the times after World War II, but also the period of the Third Republic of Poland brought a number of publications on the life of Jews in the Polish territories occupied by the Germans. Continuous research on the Holocaust is carried out to this day. They cover more and more aspects of Nazi activity in occupied Poland. An extremely interesting perspective is also the look at local communities and their inhabitants during the Second World War. It is the comparison of the image of these communities before and after the war that most clearly shows the national changes that took place as a result of the Nazi occupation activities (Urbański, 2004).

Historical sources at our disposal can illuminate the period of World War II in Szydłowiec only to a certain extent. This work is mainly based on archival materials and Jewish diaries. Oral accounts of Poles who witnessed the events of the German occupation were also used to develop it. The difficulty faced while writing the work was the question of the proper use of the collective memory of the local community. The social shaping of the forms of memory was built by people who survived World War II on the basis of common meanings ascribed to the past, sometimes they differ from the historical truth (Engelking, 2001).

\section{Research Questions}

The purpose of this article is expressed in many questions:

1. What kind of work were Jews forced to do during World War II? 
2. At what times and where was the work performed? Who sent Jews from the area of Szydłowiec to forced labor?

3. Was it possible for Jews to avoid going to labor camps?

4. What was the impact of the local Judenrat in helping people in labor camps?

\section{METHODOLOGY}

The attempt to answer the above questions will be based on the analysis of archival materials, memoirs, and audiovisual recordings. The applied research method will provide critical analysis of the historical sources, mainly of the archival materials. The most important documents which will be subjected to the detailed research are those detained in the YIVO in New York, Yad Vashem and Joint in Jerusalem, and in Polish archives like Institute of National Remembrance, Archives of the Jewish Historical Institute The project will be an analysis and interpretation of testimonies submitted by Jews and Poles who survived the German occupation in Poland, Jewish and Polish diaries, including, in particular, those prepared by Jews and memoirs written in Memorial Books.

\section{RESULTS AND DISCUSSION}

\section{Forced labor in the first months of the war}

Extremely burdensome, in many aspects, compulsion for Jews was the almost slave labor they performed for the benefit of the Germans. Every Jew had to work at least one day a week for the Third Reich (Aizenberg, p.23). Jews were used for various types of work, including snow removal from roads (Kornbroyt, 1989, p. 299; Aizenberg, p. 4). On the order of German soldiers, the Judenrat in Szydłowiec had to provide manpower to clear the snow from the designated section of the main road from Warsaw to Kraków (Milstein, 1989, p. 98; Aizenberg, 1989, p. 22-23). At the same time, another group of Jews was directed to dig up and transfer to the parish cemetery the bodies of Polish soldiers who died in September 1939. The situation was so serious that no one [no Jew - MB] dared to show in the city without a shovel or a broom (Milstein, 1989, p. 98; Aizenberg, 1989, p. 22-23). In turn, in the spring, Jews were used to meliorate fields in Zdziechów, $10 \mathrm{~km}$ from Szydłowiec. In the morning they were led there under the guards of German rifles, and their work stretched from dawn to dusk (AJIH, sygn. 484, p. 186).

Before the introduction of forced labor for the Nazis, Polish-Jewish cooperation was mainly on the commercial level. Jews traveled from village to village, offering various kinds of goods as well as craft services. However, the forced labor performed by Jews for the benefit of the Germans, introduced by the order, consumed most of their time and thus contributed to the pauperization of this nation. Forced labor forced the Jewish population to abandon their previous activities, which were usually their only source of income (Urbański, 2004).

One day, all the Jews, bachelors aged 16-30, received a summons to report the next day at six o'clock in the morning at a designated place in front of the conscription commission for a forced labor camp. About 500 young people, mostly the sole breadwinners of poor families, were sent to the camp in Józefów on the Vistula River to regulate the river. Soon desperate news began pouring in from there. They received almost no food, they had to eat their own money. They were paid a few pennies a day. They slept on the bare ground. The terrible dirt caused lice to crawl over them by the millions. But the worst thing was the murderous work. Half a day to belly in the water, and half a day to haul sand uphill in wheelbarrows to the coastal embankment. No wonder that bitterness and uproar among Jews from Szydtowiec, and especially among mothers working in the camp, reached its zenith (AIJH, Finkler, p. 29; Eisenberg, 1989, p. 172-173; Rosenberg, 1989, p. 18-45, 183).

The above account differs slightly from the memoirs of I. Milsztajn, who noted in his diary the date of his forced intercession before the conscription commission in the Szydłowiec town hall on August 20, 1940. According to him, all unmarried men were to report at 8 am to Judenrat. Failure to report to the commission resulted in taking the father or someone close from the family to work instead (Milstein, 1989, p.102). According to A. Finkler, even the only breadwinners were taken to the labor camp. However, I. Milsztajn claims that men who had a certificate of sole breadwinner status were released home. His account is confirmed by B.-Z. Rosenberg, who was released from the town hall (Rosenberg, 1989, p. 189) thanks to this certificate. It should be noted that the doctor conducting the examination hardly rejected anyone, and then the qualified persons, without the possibility of saying goodbye to their families, were directed to the carriages going towards Lublin (Milstein, 1989, p. 102; Rosenberg, 1989, p. 189).

\section{Work camps near Szydłowiec}

In Józefów Jews from Szydłowiec were divided into two groups, one of which was sent to the camp in Janiszów, and the other was left on the spot (Weisbrot, 1989, p. 282; Henig, p. 330): The camp in Józefów was located in a school; the rest of the people were placed in the stable, where they had to prepare plank bunks for themselves. We slept on these boards after hard work without straw and blankets (Weisbrot, 1989, p. 282; Henig, 1989, p. 330).

During the first days of their stay in the camp in Janiszów, Jews, under the supervision of the Austrian commandant Schmidt worked at building barracks. For bribes, Schmidt transferred people to lighter work and even fired them home (Milstein, 1989, p. 102; Henig, 1989, p. 332),. Later, the commandant could not be bribed, as Schmidt was replaced by Gremeisen, who immediately introduced the regime in the camp (Henig, 1989, p. 332). Already during the first roll call, he chose a group of men who did not like him and sent them to the camp in Bełżec (Milstein, 1989, p. 103). 
The workers were given a cup of black coffee (Milstein, 1989, p. 102, Weisbrot, 1989, p. 282) as their first meal for a full day's work, after which the Nazis divided the Jews into work groups, each with a specific task to perform. Some built barracks, others worked on the regulation of the banks of the Vistula, and still others built levees along this river. Their daily working time was 10 hours, with 80 wheelbarrows of dirt (Henig, 1989, p. 331; Weisbrot, 1989, p. 282) being the norm. For each group of twenty, a leader was also appointed who was responsible for the timely execution of the work and the allocation of food rations (Milstein, p. 102; Henig, p. 330). The guards were Poles, Ukrainians and Germans (Milstein, p. 102). Work in the camp was supervised with an "iron hand". Every Sunday, regardless of the weather, the Jews were led down the river where they underwent the delousing process. At that time, the workers hugged each other in order to be able to warm up at least a little (Engelking, 2001).

I. Milsztajn confirms A. Finkler's account of food rations provided for workers: a slice of bread, soup and coffee (Milstein, 1989, p. 102; AJIH, Finkler, p. 29). There was a shop in the camp run by a woman named Wajnsztok from Apol. At this point, you could buy bread, marmalade and other groceries (Eisenberg, 1989, p. 173; Milstein, 1989, p. 103 ). After obtaining the appropriate permission, the families could visit the workers in the camp. Those who managed to come to the camp for a visit brought parcels from families who could afford to pass something on to their relatives in the camp (There were about 500 Jews from Szydłowiec in the camps in Janiszewo and Józefów, among them: Mendl Katz, H. and S. Rotman, Gerszon Cukier, brothers Brones, Abba Ingerowicz, brothers Wolowski, Meir Buchbinder, Gerszon Kochan, Szaweł Zlatowicz, Szyja Szwarcfuter, Jekutiel Gzemba) (Milstein, 1989, p. 104). The Judenrat was also allowed to deliver parcels with food, underwear and clothes to Jews in the camp, which, according to A. Wajsbrot, helped [them - M.B.] to survive these terrible conditions (Weisbrot, 1989, p. 282).

Due to the deteriorating conditions in the camp: small food rations (Semayaticki-Sharfhartz, p. 282), lack of money to buy food products, spread of diseases (Pilichowski, 1979, p. 213), increasingly colder nights and exhausting work done barefoot in cold water, the Jews began to think about escape. The first ones who failed to escape were Jankiel Kiszkat and Eliasz, half-brother of Rifka Kriss (Milstein, 1989, pp. 103-104). The guards caught Elijah in one month, and Jankiel was shot while escaping. His body, with the support of the Szydłowiec Judenrat, was handed over to his parents who buried him in the Jewish cemetery in Szydłowiec (Milstein, 1989, pp. 103-104).

On September 11, 1940, those who had managed to survive several months of exhausting work were released home. It happened thanks to the efforts of the Szydłowiec Judenrat, and especially one of their members, A. Finkler (Milstein, 1989, p. 106; Henig, 1989, p. 332). The Szydłowiecki Judenrat took action due to the efforts of the families that remained in the city: one evening, the parents of the deported youth stormed the Judenrat office. Crying and screams forced the Council to take up the matter immediately (Finkler, 1989, p. 151). Three members of the Judenrat, Lejbuś Dimont, Aaron Szarfharc and Abraham Finkler, took steps to free Jews from Szydłowiec from the camp in Janiszewo. However, due to the personal problems of two of them, A. Finkler completed the task assigned to them by himself. This is how he describes the sight he found in the Janiszów camp: I looked around among these young people, all my students who used to be. Now they were ragged, barefoot, their faces stretched out and glum, almost unrecognizable (Finkler, 1989, p. 151-152).

Unfortunately, he did not manage to free all the Jews who were held in the camp in Józefów. Therefore, some of those who remained in the camp decided to escape over time (Milstein, 1989, p. 106; Weisbrot 1989, p. 283). However, it is likely that some Jews from Szydłowiec worked there until it was closed in March 1942 (Słonimski, 2000).

In the following years, several new labor camps were established near Szydłowiec, incl. in Jedlnia, Wolanów, Wiśniówka (Milstein, 1989, p. 107, AJIH, Ajzenberg, p. 6) (a quarry) and Wyszków. And in 1942, a quarry in Śmiłów also began to function. The Szydłowiec Judenrat had to provide workers to all these camps. The selection of employees was supervised in the town hall in Szydłowiec by the head of the German labor office, Rybitski. It was his idea that the card work system was (Törnquist-Plewa, 2006).

Every week he personally stamped job cards at the local town hall. Risking their lives, some people forged Rybitski's stamp. It is worth noting that people with a certificate of employment in an enterprise located in Szydłowiec were not sent to the labor camps (Milstein, 1989, p. 108). From the summer of 1942, it was very dangerous for Jews to go out to the streets of Szydłowiec, because the walks risked being rounded up and being sent to forced labor in the camp (Shapshewish, 1989, p. 310; AJIH, Aizenberg, p. 4).

\section{Illegal work}

The huge number of bans imposed on Jews also made their situation worse. The ban on the ability to perform certain professions by Jews was very burdensome, including - which is worth emphasizing - the ban on baking bread and performing activities related to the tanning industry. Nevertheless, the Jews secretly performed these activities, because, as B.T. Rosenberg: My mother started baking bread for sale. It was a dangerous job, but what else could we do? (...) Necessity did not allow us the luxury of fear (Rosenberg, 1989, p. 188).

The second of these prohibitions particularly hit the Jewish population of Szydłowiec, because before the outbreak of World War II, there were as many as three tanneries in the town which they owned. Therefore, from 1940, Jews undertook illegal activities (Piątkowski, 2009). 
They were located [illegal workplaces - M.B.] mostly in the apartment itself, or in an adjacent cell, more or less masked. Usually in the second room, the door of which was blocked by a wardrobe. There were several barrels there, where the skins were tanned, stirring them continuously for many hours with a pole or simply with your hands. After five days of various operations, the skins were ready to be obtained. It was a dirty, tiring and risky job. In almost every other house there was such a tannery. In a successful incident, when the batch of skins was successful, wages were minimal due to great competition. Otherwise, when the party failed, not only the weekly earnings were wasted, but also more money had to be added (...) The millers' earnings were not better or even much worse. Throughout the day, by turning the grinder's crank for several hours in a stuffy, tightly closed room, so that even the drone does not come out, completely white from the dust on the lungs, they could grind just a dozen kilos, which was rarely enough for poor maintenance (AJIH, Finkler, pp. 24-25).

There are cases where the denunciators discovered illegal jobs (Milstein, 1989, p. 112; Eisenberg, 1989, pp. 171-173). As B.T. Rosenberg: Some Jews risked their lives and lost them in this deadly struggle to survive (Milstein, 1989, p. 110). For example, I. Milsztajn wrote in his memoirs: Someone informed that Sara Ita Freed, wife of Beniamin Lazer Jankiel, illegally bakes bread. Swedko and Smidka burst into the apartment and it turned out that the stove was warm. They shot her on the spot (Rosenberg, 1989, p. 191).

By forbidding Jews from engaging in the tanning industry, the Nazis struck a large group that profited from it, ranging from people providing leather to manual workers and sellers of finished products. Only the Nuty and Smerl Ejzenberg (Krajewski, 1989, p. 220; Milstein, 1989, p. 99-100; APR, file: F-453, D-405, M-1012, K-1884, W-974)) tannery operated legally in the city under the supervision of the Nazis. However, many Jews, risking their lives, decided to illegally produce leather. They hid makeshift tanneries in camouflaged rooms of their homes or in the houses of Poles (Piatkowski, 2009).

There have been cases of inspections by the German Price Control Authority in private homes. The commander of that office discovered in Szydłowiec that Izrael and Joszua Henig had leather of considerable value, which he ordered to be transported to the local town hall, and the prisoners to be interrogated. At that time, thanks to the efforts of the Szydłowiec Judenrat, it was possible to free both prisoners. Probably, the money and jewelry collected by J. Henig's mother were not even needed for this, because the Judenrat activists knew this official and thus managed to communicate with him through negotiations (Milstein, 1989, p. 100).

The ban on teaching among Jews paralyzed Jewish education. Nevertheless, the Jews educated their children in secret from the occupiers. In Szydłowiec, we know of at least one case of a kindergarten that was run in the house of I. Milsztajn's sister. The kindergarten was run by three educated women from Łódź, who, apart from taking care of children, taught them Yiddish and Polish. Due to the costs of running the kindergarten, its participants were children from well-to-do families. Their activities were discontinued only after the first deportation to the Treblinka camp (Milstein, 1989, p. 100).

Despite the Nazi order for Jews to hand over all goods, skins and articles from their shops, some of them decided to hide their goods in hiding places. Thanks to this, they could continue to trade in secret. According to the accounts of the survivors, there were denunciators of Polish and Jewish origin in the city, who informed the occupiers about the nonobservance by Jews of the orders and bans provided for by the Third Reich legislation: For our great shame, Jewish informers were active in the city. In early summer, the police showed up and carried out mass checks. It operated on the basis of information provided by Jewish informers (Eisenberg, 198, p. 172; Pomerantz, 1989, p. 309). Such checks were brutal as they were often carried out by force at night. During their conduct, Jews were ordered to tear off the floors of their houses or dig the ground in order to check whether they were hiding anything (Törnquist-Plewa, 2006).

The prohibition for Jews to be burdensome was the restriction of the possibility of moving around the country, which was introduced at the end of 1940 (Eisenberg, 1989, p. 172). It was a blow for the members of the nation which dealt mostly with trade, which either completely prevented them from making a profit, or forced them to undertake risky, illegal movement around the country and smuggle various types of goods. Many inhabitants of Szydłowiec, despite the prohibition of movement, were still engaged in trade. The only group that could leave the ghetto and travel around the country were the so-called greens who, at the request of the Germans, collected old rags and scrap metal (Milstein, 1989, p. 106).

\section{CONCLUSION}

World War II experiences cannot be viewed in binary terms. That is why it is so important to individually analyze the history of each witness of past events. The memories of people from Szydłowiec and the surrounding area who survived the period of the Nazi occupation, presented by me, have been selected in such a way as to present the situation of the local population in terms of forced labor as broadly as possible.

The collected archival sources, diaries of Holocaust survivors and oral reports made it possible to present the image of the war as seen through the eyes of the then inhabitants of the city (Słomińska-Paprocka, 2000). The period of World War II in Szydłowiec has not been elaborated so far, hence it was important to take action to change this state of affairs, because, as Elie Wiesel said: If we cannot imagine the past, then we cannot imagine the future (Pomeranz, 1989, p. 244). 


\section{LIMITATION AND STUDY FORWARD}

This study is limited to discussing the forced labor of Jews in the Szydłowiec region. Maybe for further research helpful in carrying out the same research on other lands included in the Radom District or the entire General Government.

\section{REFERENCES}

1. Aizenberg M. Archives of the Jewish Historical Institute, Testimonies, sygn. 302/6.

2. AJIH (Archives of the Jewish history Institute). Żydowska Samopomoc Spoleczna, sygn. 484.

3. AJIH (Archives of the Jewish history Institute). Memoirs, Abraham Finkler, sygn. 302/6.

4. APR (Archive in Radom). Files of Prisoners, file no. F-453, D-405, M-1012, K-1884, W-974.

5. Eisenberg M. (1989). Running, [in:] Memorial Book of Szydłowiec, ed. B. Kagan, New York.

6. Engelking B. (2001). Zagłada i pamięć, Warsaw.

7. Finkler A. (1989). A ghetto, [in:] Memorial Book of Szydtowiec, red. B. Kagan, New York.

8. Henig I. (1989). The first labor camps, [in:] Memorial Book of Szydtowiec, ed. B. Kagan, New York.

9. Kornbroyt O. (1989). From Juzefów to Hasag, [in:] Memorial Book of Szydłowiec, ed. B. Kagan, New York.

10. Krajevski B. (1989). Out of, , [in:] Memorial Book of Szydłowiec, ed. B. Kagan, New York.

11. Milstein I. (1989). Chronicle, [in:] Memorial Book of Szydtowiec, ed. B. Kagan, New York.

12. Piątkowski S. (2009). Więzienie niemieckie w Radomiu 1939-1945, Lublin.

13. Pilichowski C. (1974). Nazi camps in Poland 1939-1945. Encyclopedic booklet, Warsaw.

14. Pomerantz J. (1989). Kingdom of death, [in:] Memorial Book of Szydłowiec, ed. B. Kagan, New York.

15. Rosenberg B.T. (1989). Escape from, [in:] Memorial Book of Szydlowiec, ed. B. Kagan, New York.

16. Semyaticki-Sharfhartz T. (1989). From Szydłowiec, [in:] Memorial Book of Szydłowiec, ed. B. Kagan, New York.

17. Shapshewish, Starbcjowicz J., (1989). Memorial Book of Szydłowiec, ed. B. Kagan, New York.

18. Słomińska-Paprocka D. (2000). Szydłowiec i okolice, Szydłowiec.

19. Słonimski A. (2007). Elegia miasteczek żydowskich, [in:] Przechować pamięć tamtych dni, ed. G. Miernik, Szydłowiec.

20. Törnquist-Plewa B. (2006). The Tale of Szydtowiec. Memory and Oblivion in a Former Shtetl in Poland, [in:] The Holocaust in post-war battlefields: genocide as historical culture, ed. K. Karlsson, U. Zander, Sekel Bokfoerlag.

21. Urbański K. (2004). Zagłada Żydów w dystrykcie radomskim, Cracow.

22. Weisbrot A. (1989). Ghetto, hiding-place and camp, [in:] Memorial Book of Szydtowiec, ed. B. Kagan, New York. 